\title{
Pengaruh Religiusitas Terhadap Penerimaan diri Orangtua Anak Autis di Sekolah Luar Biasa XYZ
}

\author{
Siti Rahmawati ${ }^{1}$ \\ ${ }^{1}$ Program Studi Psikologi, Fakultas Psikologi dan Pendidikan, Universitas Al Azhar Indonesia, \\ Kompleks masjid Agung Al Azhar, Jalan Sisingamangaraja, Kebayoran Baru Jakarta Selatan, 12110 \\ Penulis untuk Korespondensi/E-mail: siti_rahmawati@uai.ac.id
}

\begin{abstract}
Abstrak - Riset ini bertujuan untuk mengetahui pengaruh religisitas dan penerimaan diri orang tua dari anak autis di SLB XYZ di Bekasi. Setiap orang tua menginginkan anaknya dapat lahir dan tumbuh secara sempurna, namun ketika kenyataan yang harus dihadapi tidak sesuai dengan harapan, seringkali orang tua menyalahkan Tuhan dan tidak mau menerima keadaan anaknya. Penerimaan diri (self acceptance) adalah sikap yang pada dasarnya merasa puas dengan milik sendiri, kualitas dan bakat sendiri, dan pengakuan akan keterbatasan diri sendiri, sikap yang menunjukkan rasa puas terhadap dirinya, baik kekurangan maupun kelebihannya, sehingga dapat membentuk harapan yang realistic terhadap dirinya dan menghargai dirinya sendiri. Religiusitas adalah seberapa jauh pengetahuan, seberapa kokoh keyakinan, seberapa tekun pelaksanaan ibadah, seberapa dalam penghayatan agama yang dianut seseorang dan pengalaman individu dalam beribadah. Metode penelitian yang digunakan adalah penelitian kuantitatif, pegumpulan data dilakukan menggunakan skala religiusitas dan penerimaan orang tua. Sampel pada penelitian ini adalah 80 orangtua pada anak autis di SLB XYZ. Penelitian ini menggunakan teknik accidental sampling. Hasil penelitian menunjukkan bahwa terdapat pengaruh antara Religiusitas dan Penerimaan diri orangtua. Hal ini ditunjukkan dengan hasil $(R=0,382)$ dengan nilai adjusted $R$ square $=0,146$ dan $p=0,000$ di mana $p<0,05)$ artinya, semakin tinggi religiusitas pada orang tua maka semakin tinggi penerimaan diri orangtuanya.
\end{abstract}

\section{Kata Kunci - Religiusitas, Penerimaan Diri, Autis}

Abstract - This research aims to determine the influence of the religiosity and self-acceptance of parents of children with autism in SLB XYZ in Bekasi. Every parent wants his child to be born and grow perfectly, but when the reality to be faced does not match expectations, often parents blame God and do not want to accept the state of his son. Self-acceptance is an attitude that is basically satisfied with one's own self, quality and talent, and acknowledgment of one's own limitations, an attitude that expresses a sense of self-satisfaction, both its shortcomings and its advantages, so as to form a realistic expectation of itself and appreciate himself. Religiosity is how far the knowledge, how strong the belief, how diligent the implementation of worship, how deep appreciation of one's religion and the experience of individuals in worship. The research method used is quantitative research, data collection is done using the scale of religiosity and acceptance of parents. The sample in this study were 80 parents in children with autism in SLB XYZ. This research use accidental sampling technique. The results showed that there is influence between Religiosity and Self-Acceptance of parents. This is indicated by the result ( $R$ $=0.382$ ) with adjusted value $R$ square $=0,146$ and $p=0,000$ where $p<0,05$ ) meaning, the higher religiosity in parent hence the higher the parent self acceptance.

Keywords - Religiosity, Self-Acceptance, Autism 


\section{PENDAHULUAN}

$\mathrm{K}$ ehadiran anak merupakan saat yang ditunggu-tunggu dan sangat menggembirakan bagi pasangan suami istri. Lahirnya seorang anak diharapkan dapat menambah kuat ikatan cinta, bukan hanya bagi suami istri tetapi juga bagi keluarga besar masing-masing. Setiap orang tua mengharapkan anak yang dimilikinya dapat lahir dan tumbuh secara normal dan berkembang secara sempurna, namun pada kenyataannya seringkali orang tua merasa kecewa dan sedih jika anak yang dilahirkan tidak sesuai dengan yang diharapkan dan menunjukan masalah perkembangan. Anak yang kehadirannya dinanti-nantikan bisa saja memiliki keterbatasan, baik secara fisik ataupun non fisik, dan hal ini tentu saja menimbulkan kekecewaan bagi orang tua.

Anak berkebutuhan khusus atau anak luar biasa adalah anak yang menyimpang dari rata-rata anak normal dalam hal ciri-ciri mental, kemampuan-kemampuan sensorik, fisik dan neuromaskular, perilaku social dan emosional, kemampuan berkomunikasi, maupun kombinasi dua atau lebih dari hal-hal di atas (Mangunsong, 2009). Jenis-jenis anak berkebutuhan khusus yaitu, tunanetra, tunagrahita, tunarungu, tunadaksa, tunalaras, kesulitan belajar, cerebral palsy, autism, anak berbakat (gifted), rett's disorder, Asperger, lamban belajar (slow learner), dan ADHD (Mangunsong, 2009).

Gangguan autisme ditemukan pertama kali oleh Leo Kanner pada tahun 1943, Leo Kanner mengemukakan tentang anak-anak dengan gejala autisme yang disebut dengan early infantile autism atau anak autistik usia dini. Gangguan autisme ini dinyatakan sebagai ketidakmampuan berinteraksi dengan orang lain, gangguan berbahasa yang ditunjukkan dengan penguasaan bahasa yang tertunda, echolalia, pembalikan kalimat, adanya aktivitas bermain repetitive dan stereotype, rute ingatan yang kuat dan keinginan obsesif untuk mempertahankan keteraturan di dalam lingkungannya.

Terdapat tiga pengertian autisme (Chaplin, 2000), pertama, cara berpikir yang dikendalikan oleh kebutuhan personal atau diri sendiri. Kedua, menanggapi dunia berdasarkan penglihatan, harapan sendiri dan menolak realitas. Ketiga, keasyikan ekstrim dengan pikiran dan fantasi sendiri.

Autisme didefinisikan sebagai suatu gangguan perkembangan yang kompleks menyangkut komunikasi, interaksi sosial, dan aktivitas imajinasi. Gejalanya mulai tampak sebelum anak berusia 3 (tiga) tahun, bahkan pada autism infantile, gejalanya sudah ada sejak lahir.

Jumlah penyandang gangguan autism semakin bertambah di setiap tahun. Di Amerika Serikat, kelainan autisme 4 (empat) kali lebih sering ditemukan pada anak lelaki dibandingkan anak perempuan dan lebih sering banyak diderita anak-anak keturunan Eropa Amerika dibandingkan yang lainnya. Di Indonesia, pada tahun 2013 diperkirakan terdapat lebih dari 112.000 anak yang menderita autisme dalam usia 5-19 tahun. Sedangkan prevalensi penyandang autisme di seluruh dunia menurut data UNESCO pada tahun 2011 adalah 6 di antara 1000 orang mengidap autisme. Gangguan autisme lebih sering terjadi pada anak laki-laki dibandingkan pada anak perempuan dengan perbandingan 3:1 atau 4:1, namun biasanya penyandang autis pada anak perempuan akan memiliki gejala yang lebih berat dan hasil tes intelegensinya lebih rendah dari pada anak laki-laki (Mangunsong, 2009).

Beragam respon yang dilakukan orang tua ketika pertama kali mengetahui anaknya mengalami gangguan autisme. Pada umumnya orang tua akan bersedih, tidak percaya diri, dan malu. Peran serta orang tua dalam memberikan penanganan kepada anak autisme secara cepat, tepat, terarah, dan sedini mungkin dapat memberikan kesempatan yang besar kepada anak agar dapat hidup mandiri (Marijani, 2003).

Penerimaan orang tua ditandai oleh perhatian besar dan kasih sayang kepada anak. Orang tua yang menerima anaknya akan memperhatikan perkembangan dan kemampuan anak serta memperhitungkan minat anak (Hurlock, 2000). Penerimaan ditandai dengan sikap positif, adanya pengakuan atau penghargaan terhadap nilai-nilai individual tetapi menyertakan pengakuan terhadap tingkah lakunya (Chaplin, 2000). Dapat dikatakan bahwa penerimaan orang tua merupakan dasar bagi setiap orang 
untuk dapat menerima kenyataan hidup, semua pengalaman baik ataupun buruk.

Bentuk penerimaan orang tua terhadap anak dengan gangguan autism beraneka ragam Terdapat dua bentuk penerimaan orang tua terhadap anak dengan gangguan autism (Hurlock, 2000). Bentuk pertama adalah memahami keadaan anak apa adanya (positif, negatif, kelebihan dan kekurangan). Pada umumnya orang tua dapat memahami keadaan anak apa adanya, contohnya anak yang di dagnosis menderita autisme tidak dapat berbicara, mempunyai kontak mata yang kurang lama, sering melakukan gerakan yang berulang, senang menyendiri, berjalan jinjit, aktif dan tidak peduli terhadap lingkungan sekitar.

Penerimaan orang tua sangat mempengaruhi perkembangan anak autisme di kemudian hari. Sikap orang tua yang tidak dapat menerima kenyataan bahwa anaknya memiliki gangguan autisme akan sangat buruk dampaknya, karena hal tersebut hanya akan membuat anak autisme merasa tidak dimengerti dan tidak diterima apa adanya serta dapat menimbulkan penolakan dari anak dan dalam perilaku yang tidak diinginkan. (Hurlock, 2000). Orang tua memiliki peran yang besar dalam proses penyembuhan penderita autism. Hal ini berkaitan dengan sikap penerimaan orang tua terhadap anak autisme yang ditunjukkan dalam perilaku menghadapi anak autisme. Sikap menerima setiap anggota keluarga sebagai tingkah lanjutan yaitu dengan segala kelemahan, kekurangan, dan kelebihannya seharusnya mendapat tempat dalam keluarga. Setiap anggota keluarga berhak atas kasih sayang orang tuanya. Penerimaan orang tua terhadap anak autis memerlukan pengetahuan yang lebih tentang autisme itu sendiri, sehingga orang tua akan memahami arti dari autisme sebenarnya.

Salah satu faktor yang mempengaruhi penerimaan diri orangtua adalah agama (Hurlock, 2000). Agama mempengaruhi penerimaan atau penolakan orang tua terhadap anak yang mempunyai kekurangan, karena dengan agama juga diharap bisa mengontrol emosi yang berlebihan dalam diri seseorang, terutama emosi yang dialami orang tua dalam penerimaan anak mereka yang mengalami kekurangan dan keterbatasan.
Fenomena yang terjadi pada orang tua anak autis adalah, orang tua dari anak gangguan autisme mengaku bahwa masih kurang dibekali oleh faktor agama, jadi ketika orang tua tersebut memiliki anak dengan gangguan autisme menjadi shock, malu, tidak bersyukur, stress,bahkan tidak mau menerima takdir yang terjadi di kehidupannya dan ingin melakukan hal yang dibenci oleh agama. Dengan sikap orang tua yang seperti itu, membuat anak gangguan autisme menjadi lebih menjauhkan diri dari teman-temannya, tidak ingin tahu dengan lingkungan sekitar.

Al-Qur'an banyak memberikan gambaran mengenai besarnya peran anak dalam kehidupan. Di sisi lain, anak juga dapat menjadi ujian dan cobaan bagi orang tua. Orangtua memiliki kewajiban untuk menjaga anak-anaknya, walau anak terlahir dalam keadaan tidak sempurna. Bukanlah hal yang mudah bagi orangtua menerima keadaan anaknya yang mengalami gangguan autisme, tetapi pada faktanya kebanyakan anak-anak yang mengalami gangguan autisme dapat mandiri dengan sentuhan para orang tua mereka yang ikhlas merawat anak autis tersebut.

\section{KERANGKA TEORI}

\section{Penerimaan Diri Orang Tua}

Banyak ahli yang memberikan definisi tentang penerimaan diri. Dalam definisi tersebut terdapat adanya perbedaan definisi yang dipengaruhi oleh adanya perbedaan sudut pandang dari masing-masing ahli. Penerimaan diri adalah suatu tingkat kemampuan dan keinginan individu untuk hidup dengan segala karakteristik dirinya. Individu yang dapat menerima dirinya diartikan sebagai individu yang tidak bermasalah dengan dirinya sendiri, yang tidak memiliki beban perasaan terhadap diri sendiri sehingga individu lebih banyak memiliki kesempatan untuk beradaptasi dengan lingkungan (Hurlock, 2000).

Selanjutnya, penerimaan diri juga didefinisikan sebagai memiliki pandangan yang positif tentang diri sendiri, mengakui dan menerima berbagai aspek diri termasuk kualitas baik dan buruk yang ada pada dirinya dan memandang positif terhadap kehidupan yang telah dijalaninya (Ryff \& Keyes, 1995). Hal ini 
diperkuat dengan pernyataan bahwa penerimaan diri secara sederhana diartikan sebagai menerima sesuatu sebagaimana adanya dan berdamai dengan dirinya. Ketika individu betul-betul menerima dirinya, mereka kemudian memikiki ruang dan perspektif untuk memandangnya dan menanganinya dari posisi yang telah seimbang dan sehat. Ketika individu sudah bisa berdamai dengan suatu keadaan yang dihadapinya, individu tersebut akan memandang dirinya dengan cara yang positif dan realistis, sehingga seseorang tersebut akan melihat dirinya secara konsisten, serta mau mengakui dan menerima kekurangan yang ada di dalam dirinya, tidak malu dengan keadaannya dan berusaha untuk merubah keadaannya sehingga bisa menjadi lebih baik dan menjalani kehidupaan yang sehat (Robbins (2007).

\section{Aspek-Aspek Penerimaan Diri Orang Tua}

Menurut Porter (1964) aspek-aspek penerimaan diri orang tua sebagai berikut (Johnson \& Medinnus, 1974) :

1). Menghargai anak sebagai individu dengan segenap perasaan mengakui hak-hak anak dan memenuhi kebutuhan untuk mengekspresikan perasaan. 2). Menilai anaknya sebagai diri yang unik sehingga orang tua dapat memelihara keunikan anaknya tanpa batas agar mampu menjadi pribadi yang sehat. 3). Mengenal kebutuhan-kebutuhan anak untuk membedakan dan memisahkan diri dari orang tua dan mencintai individu yang mandiri. 4). Mencintai anak tanpa syarat.

\section{Religiusitas}

Secara bahasa, kata religiusitas adalah kata kerja yang berasal dari kata benda "religion". Religi berasal dari kata re dan ligare artinya menghubungkan kembali yang telah putus, yaitu menghubungkan kembali tali hubungan antara Tuhan dan manusia yang telah terputus oleh dosa-dosanya. Hawari (2002) mengungkapkan bahwa religiusitas merupakan penghayatan keagamaan dan kedalaman kepercayaan yang diekspresikan dengan melakukan ibadah sehari-hari, berdoa, dan membaca kitab suci.

Berdasarkan dengan religiusitas Islam, kualitas religiusitas seseorang ditentukan oleh seberapa jauh individu memahami, menghayati, dan mengamalkan ajaran-ajaran serta perintah
Allah secara kaffah atau menyeluruh dan optimal. Untuk mencapai hal tersebut maka diperlukan iman dan ilmu yang akhirnya berkaitan dengan amal perbuatan sehingga fungsi Islam sebagai rahmat seluruh umat manusia dan seluruh alam dapat dirasakan.

Religiusitas meliputi dimensi jasmani dan rohani, fikir dan dzikir, aqidah dan ritual, peribadatan, penghayatan dan pengalaman, akhlak, individu dan social kemasyarakatan, masalah duniawi dan akhirat, sehingga pada dasarnya religiusitas Islam melipri seluruh dimensi dan aspek kehidupan.

Religiusitas dalam Islam, memiliki tiga dimensi yaitu Aqidah (keyakinan), Syariah (praktik agama, ritual formal) dan Akhlak (pengamalan dari aqidah dan syariah (Ancok \& Suroso, 2005).

\section{Dimensi Religiusitas}

Dimensi-dimensi religiusitas adalah sebagai berikut (Kendler, 2003):

1) Dimensi general religiousity, dimana dalam dimensi ini seorang individu merefleksikan tentang perhatian dan keterlibatan dalam halhal yang berkaitan dengan spiritual, termasuk perasaan (sense) selama individu berada di dunia, dan keterlibatan Tuhan sehari-hari ketika sedang menghadapi masalah. Karena saat individu sedang dalam masa krisis (berhadapan dengan masalah), mereka akan menjadikan agama sebagai cara untuk membantunya menyelesaikan masalah. Hal ini dinamakan coping religiusitas dan berfungsi lebih cepat dan proksimal dalam memberikan implikasi terhadap kesehatan. Selanjutnya dijelaskan bahwa ada tiga jenis coping religious dalam penyelesaian masalah, yaitu : a) Berserah diri yaitu meminta penyelesaian masalah kepada Tuhan saja, yaitu dengan cara berdoa dan meyakini bahwa Tuhan akan menolong hambaNya dan menyerahkan semua keputusan kepada Tuhan, b). Kolaborasi yaitu hamba meminta solusi kepada Tuhan dan hamba-Nya senantiasa berusaha dan c).Mengandalkan kemampuan sendiri yaitu individu bertanggung jawab sendiri dalam menjalankan coping.

2) Dimensi social religiousity, dimana pada dimensi ini, individu merefleksikan dirinya terhadap hubungan kepada orang-orang disekitarnya, sikap dan kegiatan beribadah yang dijalaninya dan dilakukan secara kolektif. 
3) Dimensi forgiveness (memaafkan) dan unvengefullness (perasaan tidak dendam), yaitu dimensi memaafkan, dimana individu dapat merefleksikan dirinya sebagai individu yang penuh dengan kasih saying, perhatian dan pendekatan memaafkan kepada dunia. Individu diminta untuk tidak merasa keberatan ataupun memiliki perasaaan negative ketika diberikan suatu kejadian yang tidak menyenangkan dan tidak ada rasa penyesalan setelah kejadian tersebut hilang.

4) Dimensi God as Judge (Tuhan sebagai penetap takdir), pada dimensi ini, individu diminta untuk ikhlas karena pada dasarnya segala sesuatu yang terjadi merupakan suatu takdir yang harus dijalani. Berhubungan dengan takdir yang dimiliki oleh individu. Dan mengetahui bagaimana seorang individu memahami dan menghadapi permasalahan yang besar dalam kehidupan serta menilai kembali tentang ganjaran yang diberikan Tuhan. Dimensi ini menjelaskan tentang kepercayaan bahwa Tuhan akan memberikan ganjaran dari apa yang kita lakukan, seperti saat kita melakukan hal baik terhadap Tuhan maka Tuhan akan memberikan pahala begitu pula sebaliknya saat kita melakukan kesalahan kepada Tuhan makan Tuhan akan memberikanm hukuman atau dosa.

5) Dimensi thankfulness (bersyukur), dalam dimensi ini, individu mampu merefleksikan dirinya untuk berterima kasih kepada Tuhannya. Dimensi ini sangat berhubungan dengan cara pandang kehidupan psikologi positif, karena hubungan antara bersyukur dan keadaan kehidupan, stressor eksternal dapat mengubah perasaan bersyukur. Dan yang menjadi hal penting adalah saat seseorang dapat tetap merasa bersyukur dalam situasi yang tidak baik bagi dirinya. Sikap bersyukur menunjukkan bahwa hidup adalah karunia.

6) Dimensi involve God (keterlibatan Tuhan dalam keseharian), individu mampu menghadirkan Tuhan secara positif didalam kesehariannya. Menggambarkan kepercayaan akan adanya Tuhan dalam kehidupan seharihari, bahwa segala sesuatunya berasal dari Tuhan. Merefleksikan bahwa Tuhan merupakan cerminan dalam keyakinan individu secara aktif dan positif terlibat dalam urusan setiap individu yang ada di muka bumi ini.

\section{METODE PENELITIAN}

Jenis penelitian yang digunakan dalam penelitian ini adalah penelitian kuantitatif, yang menekankan pada data-data numerical (angka) yang diolah dengan metode statistika (Azwar, 2010).

Dalam penelitian ini, peneliti menggunakan alat pengumpulan data yang berupa Kuesioner (skala). Kuesioner (skala) adalah sejumlah pernyataan tertulis yang digunakan untuk memperoleh informasi dari responden dalam arti laporan tentang pribadinya, atau hal-hal yang ia ketahui (Arikunto, 2002). Sedangkan instrument dalam penelitian ini menggunakan model skala likert. Skala yang digunakan adalah skala tingkat Religiusitas yang diambil berdasarkan dimensi-dimensi religiusitas menurut Kendler (2003) dan skala penerimaan diri orang tua. Skala penerimaan orang tua meliputi aspek-aspek penerimaan diri orang tua yang dikemukakan oleh Porter (Johnson \& Medinnus, 1974)

\section{Sumber Data}

Sumber data (responden) dalam penelitian ini adala orang tua (ibu) wali murid anak autis SLB XYZ di Bekasi. Dari 100 orang wali murid tersebut dipilih 80 orang secara accidental untuk menjadi sumber data dalam penelitian ini.

\section{HASIL dan PEMBAHASAN}

Uji persyaratan analisis adalah uji normalitas data menggunakan Kolmogorov-Smirnov dengan SPSS untuk melihat seberapa normal suatu data dalam pendistribusiannya. Dasar pengambilan keputusan adalah jika nilai signifikansi lebih besar dari 0,05 maka data tersebut berdistribusi normal. Sebaliknya, jika nilai signifikansinya lebih kecil dari 0,05 maka data tersebut tidak bersitribusi normal. Berikut adalah tabel hasil perhitungan uji normalitas data .

Dapat dilihat bahwa nilai signifikansi untuk variabel dimensi religiusitas dan penerimaan diri orang tua sebesar 0,935. Karena signifikansi variabel lebih besar dari 0,05 $(0,935>0,05)$ maka dapat dikatakan bahwa data pada penelitian ini berdistribusi normal. 


\section{Pengujian Hipotesis}

Hipotesis yang akan diuji berbunyi : terdapat pengaruh religiusitas terhadap penerimaan diri orang tua anak autis. Untuk menguji hipotesis tersebut digunakan statistik regresi linear sederhana. Hasil analisis data diperoleh model persamaan regresi, sebagai berikut :

Tabel 1. Regresi Linier Sederhana
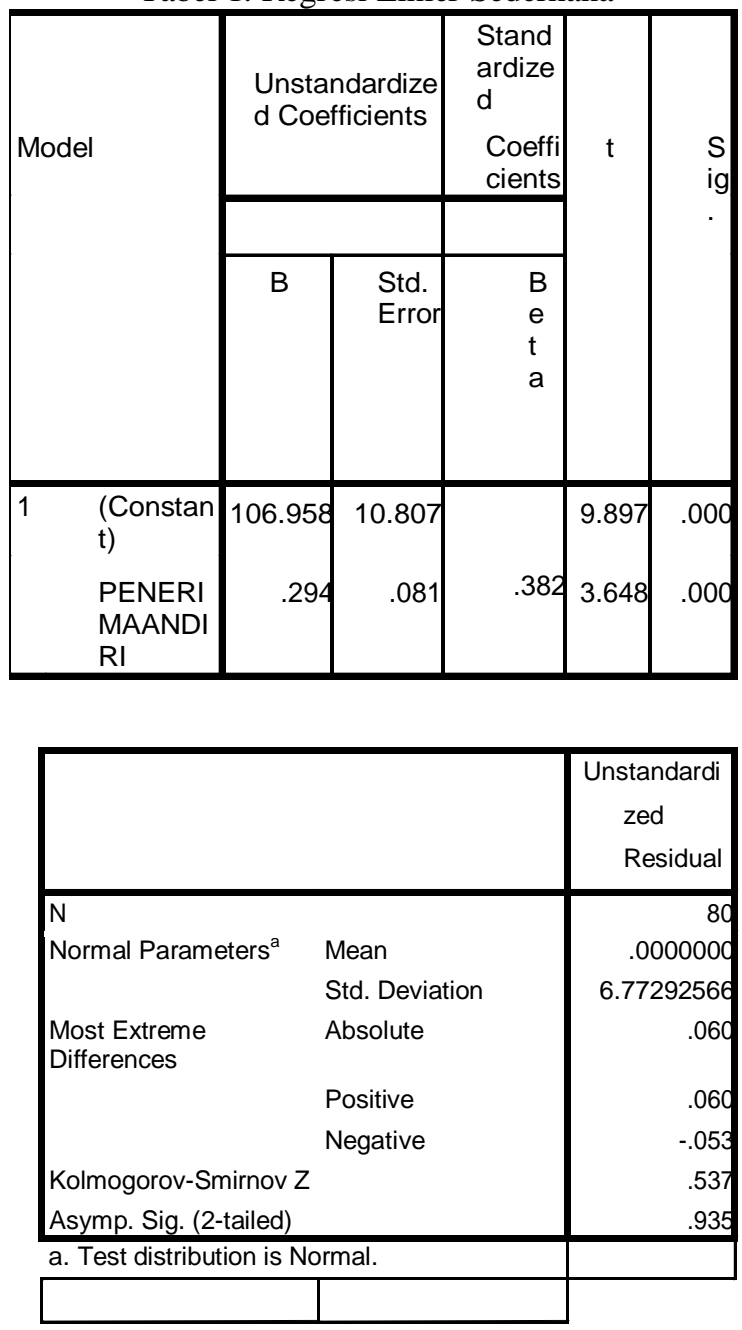

Sedangkan persamaan regresinya adalah sebagai berikut:

$\mathrm{Y}^{\prime}=\mathrm{a}+\mathrm{bX}$

Keterangan :

$\mathrm{Y}^{\prime}=$ Variabel Penerimaan Orangtua

$\mathrm{X}=$ Variabel Religiusitas

$\mathrm{a}=$ Konstanta

$\mathrm{b}=$ Koefisien Regresi (nilai peningkatan

ataupun penurunan)

$\mathrm{Y}^{\prime}=106.958+0,294 \mathrm{X}$

Pada tabel coefficient, pada kolom B constant (a) adalah 106,958, sedang nilai penerimaan diri (b) adalah 0,294. Berdasarkan model regresi tersebut menyatakan perubahan ratarata variabel $Y^{\prime}$ untuk setiap perubahan variabel X sebesar satu-satuan. Perubahan ini merupakan pertambahan bila $\mathrm{b}$ bertanda positif dan penurunan bila $b$ bertanda negatif. Maka dapat dibaca bahwa setiap perubahan 1 skor penerimaan diri akan menaikkan religiusitas sebesar 0,294 pada skor awal 106,958.

UJI F

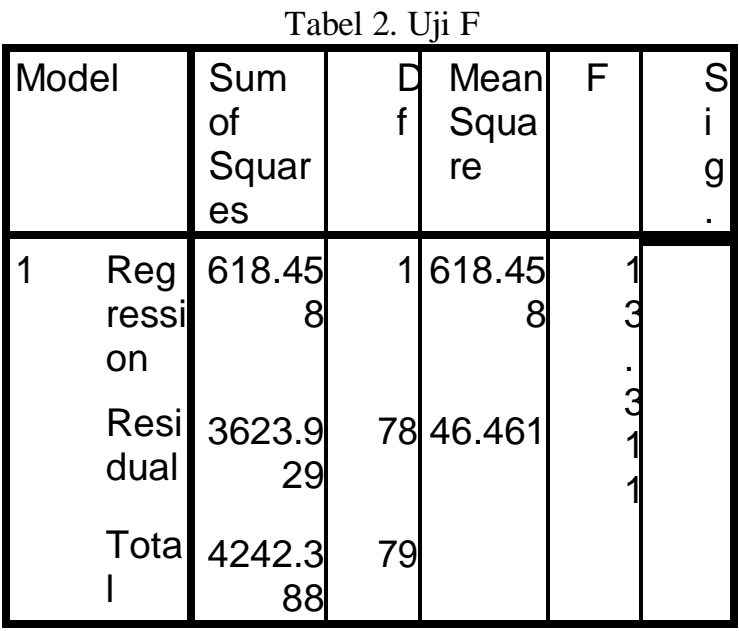

Dapat dilihat pada table bahwa nilai signifikansi yang terdapat dalam tabel yaitu 0,000 yang berarti $0,000<0,05$ maka Ha diterima. Artinya bahwa ada pengaruh yang signifikan antara variabel dimensi religiusitas dan penerimaan diri orang tua di SLB XYZ Bekasi. Persamaan regresi yang diperoleh dapat digunakan untuk menjelaskan dan mengambil kesimpulan lebih lanjut mengenai pengaruh dimensi religiusitas terhadap penerimaan diri orang tua.

\section{Uji Linieritas}

Saat dilakukan uji linieritas, diperoleh table sebagai berikut :

Berdasarkan tabel tersebut diketahui bahwa nilai signifikansi pada Linearity sebesar 0,00 artinya signifikansi kurang dari 0,05. Dapat disimpulkan bahwa persamaan regresi linear. Persyaratan linear terpenuhi maka model regresi layak dipakai untuk memprediksi dimensi religiusitas berdasarkan penerimaan diri. 
Tabel 3. Uji Linieritas

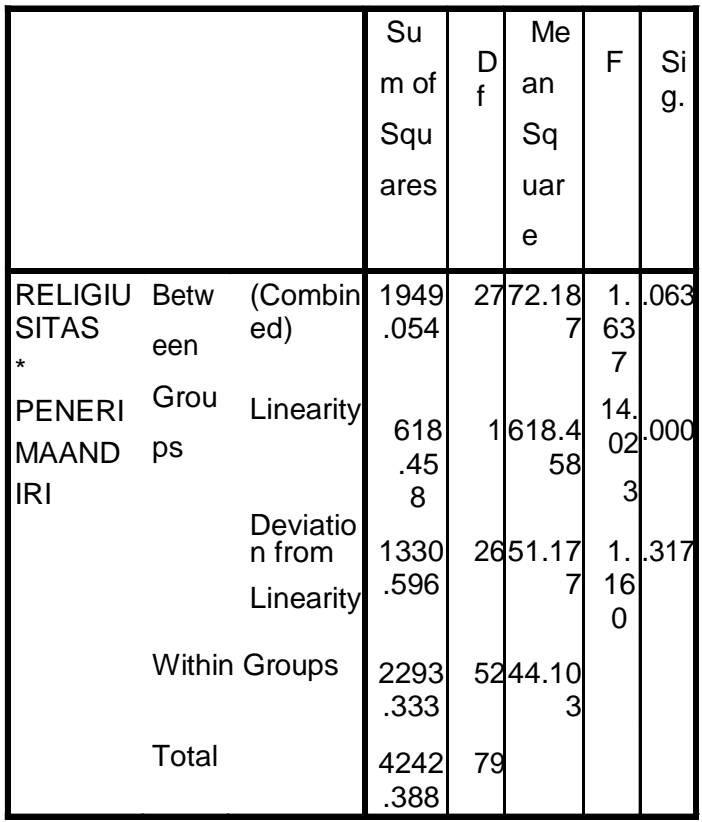

\section{Uji R2}

Uji R2 atau R square dilakukan untuk mengetahui berapa persen sumbangan IV terhadap DV. Adapun hasilnya adalah sebagai berikut :

Tabel 4. Model Summary

\section{Measures of Association}

\begin{tabular}{|l|c|l|l|l|}
\hline & R & $\begin{array}{l}\text { R } \\
\text { Squar } \\
\text { ed }\end{array}$ & Eta & $\begin{array}{l}\text { Eta } \\
\text { Squar } \\
\text { ed }\end{array}$ \\
\hline $\begin{array}{l}\text { RELIGIUSIT } \\
\text { AS * } \\
\text { PENERIMA } \\
\text { ANDIRI }\end{array}$ & 382 & .146 & .678 & .459 \\
\hline
\end{tabular}

Berdasarkan data yang diperoleh pada table di atas maka terlihat koefisien $\mathrm{R}$ square $\left(\mathrm{R}^{2}\right)$ diperoleh nilai 0,146 atau $14,6 \%$ maka dapat dinyatakan variabel dimensi religiusitas memiliki kontribusi sebesar $14,6 \%$ terhadap penerimaan diri orangtua sedangkan sisanya sebesar $85,4 \%$ dipengaruhi oleh faktor-faktor lain di luar penelitian ini.

Berdasarkan data yang diperoleh pada table di atas maka terlihat koefisien $\mathrm{R}$ square $\left(\mathrm{R}^{2}\right)$ diperoleh nilai 0,146 atau $14,6 \%$ maka dapat dinyatakan variabel dimensi religiusitas memiliki kontribusi sebesar $14,6 \%$ terhadap penerimaan diri orangtua sedangkan sisanya sebesar 85,4\% dipengaruhi oleh faktor-faktor lain di luar penelitian ini. Religiusitas dijelaskan dari dimensi-dimensi religiusitas yang dikemukakan oleh Kendler et.al (2003) seperti coping relgiousity, social support, Forgiveness (memaafkan) dan unvengefullness (perasaan tidak dendam), God as Judge (Tuhan sebagai penetap takdir), Thankfullness (bersyukur), Involve God (keterlibatan Tuhan dalam keseharian); Kendler et.al,2003). Menurut Glock \& Stark, religiusitas adalah seberapa jauh pengetahuan, seberapa kokoh keyakinan, seberapa tekun pelaksanaan ibadah, seberapa dalam penghayatan agama yang dianut seseorang dan pengalaman individu dalam beribadah (Ancok \& Suroso, 2005). Dengan kata lain, orangtua yang memiliki religiusitas tinggi akan ikhlas menerima apapun kondisi anak . Di samping itu, orangtua yang mempunyai religiusitasnya rendah maka belum bisa menerima apapun kondisi anak.

Berdasarkan hasil yang telah diperoleh, menunjukkan bahwa variabel dimensi religiusitas memiliki pengaruh positif terhadap penerimaan orangtua yang memiliki anak autis di SLB XYZ Bekasi. Hal ini dibuktikan dengan dimensi religiusitas dan penerimaan orangtua menunjukkan pengaruh sebesar 14,6\%. Artinya, pada orangtua dimensi religiusitas berpengaruh positif terhadap penerimaan orangtua. Jika dimensi religiusitas orangtua baik maka penerimaan orangtua jadi lebih baik. Sebaliknya, jika religiusitas orangtua buruk maka penerimaan orangtua akan buruk.

\section{PENUTUP}

\section{Kesimpulan}

Dari hasil penelitian diperoleh kesimpulan bahwa terdapat pengaruh yang positif antara religiusitas dengan penerimaan diri orang tua penderita autis. Semakin tinggi religiusitas yang dimiliki, orang tua akan lebih mudah menerima dan memahami keadaan anak dan tetap memberikan pendampingan yang optimal kepada anak yang menderita autis. Sebaliknya, jika religiusitas orang tua kurang baik, maka penerimaan diri terhadap anak yang menderita autis menjadi kurang baik. Hal ini akan mempengaruhi proses penyembuhan ddan 
pengembangan diri anak sehingga pertumbuhannya kurang dapat optimal.

\section{Saran}

Saran yang disampaikan dalam penelitian ini adalah pentingnya meningkatkan religiusitas kepada para orang tua penderita autis. hal ini dapat dilakukan dengan memberikan informasi dan pemahaman yang berkaitan dengan aspekaspek religiusitas dikaitkan dengan kondisi anak autis dan situasi yang dialami. Orang tua perlu diberikan pemahaman bahwa orang tua memiliki peran yang sangat penting dalam mendampingi anak autis, sehingga penerimaan diri orang tua dapat mempengaruhi perkembangan anak autis agar tumbuh optimal.

\section{DAFTAR PUSTAKA}

[1] Ancok, D., \& Suroso, F. N. 2005. Psikologi Islam: Solusi Islam Atas problem-Problem Psikologi. Yogyakarta: Pustaka Pelajar.

[2] Arikunto, S. 2002. Prosedur Penelitian, Suatu Pendekatan Praktik. Jakarta: Rineka Cipta.
[3] Azwar, S. 2010. Reliabilitas dan Validitas. Yogyakarta: Pustaka Pelajar Offset.

[4] Chaplin, J. P. 2000. Kamus Lengkap Psikologi. Jakarta: Raja Grafindo Persada.

[5] Hurlock, E. B. 2000. Perkembangan Anak. Jakarta: Erlangga.

[6] Johnson, R., \& Medinnus, G. 1974. Child Psychology Behavior And Development 6th edition. USA: John Wiley \& Sons.

[7] Kendler. 2003. Dimensions of Religiosity and Their Relationship to Lifetime Psychiatric and Substance Use Disorders. Religiosity and Psychiatric Disorder, 496503.

[8] Mangunsong, F. 2009. Psikologi dan Pendidikan Anak Berkebutuhan Khusus. Depok: Universitas Indonesia.

[9] Ryff, C. D., \& Keyes, C. M. 1995. The Structure of Psychological Well Being Revisited. Journal of Personality dan Social Psychology , 719-727. 